American Journal of Economics and Business Administration 4 (1): 94-104, 2012

ISSN 1945-5488

(C) 2012 Science Publications

\title{
Reducing the Hindering Forces in Intra-Family Business Succession
}

\author{
${ }^{1}$ George S. Vozikis, ${ }^{2}$ Eric W. Liguori, ${ }^{3}$ Brian Gibson and ${ }^{4}$ K.M. Weaver \\ ${ }^{1}$ Department of Management, \\ Institute for Family Business, Craig School of Business, \\ California State University, 5245 N. Backer, M/S PB7, CA 93740-800, Fresno \\ ${ }^{2}$ Department of Management, California State University, Fresno \\ ${ }^{3}$ Research and Curriculum Development, \\ TOP Education Institute, Sydney, NSW, Australia \\ ${ }^{4}$ Department of Management, University of South Alabama, Alabama, USA
}

\begin{abstract}
The majority of research has focused on how families can best prepare to hand the family business to the next generation and concentrated mainly on factors that facilitate succession. However, very few studies attempted to discover a set of factors that may inhibit and prevent intra-family succession. In this study we develop research propositions regarding the impact of the antecedent issues inhibiting the critical success factors for effectiveness and satisfaction with an intra-family successful succession. It is hoped that the conceptual framework advanced in this study and further empirical work will give us a much better understanding of the various issues that inhibit and possibly prevent intra-family succession such as, the process issue of identity confirmation; the individual issue of the owner's age; the relation issue of the family firm's degree of formalization; the context issue of outside options for potential successors and; the financial issues of low capital stock and variability of earnings.
\end{abstract}

Key words: Family business successions, hindering forces, idiosyncratic knowledge

\section{INTRODUCTION}

Family firms are considered as one of the engines of the post-industrial growth process since they are so important for intergeneration development and transfer of entrepreneurial talent, business success, long-term strategic commitment and entrepreneurial independence (Poutziouris, 2001), as well as, economic development in local communities (Astrachan et al., 2003; McCann and Bowman-Upton, 2001).

In the US alone, family firms represent $90 \%$ of all businesses (Dyer, 1986), while the global percentage is also high and stands around $70 \%$. Family firms are viewed as entrepreneurial firms, the ownership and management of which, more often than not, belongs to a family (Burch, 1972; Barnes and Hershon, 1976). Others contend that the classification is valid only when there has been at least one generation transfer (Ward, 2010), while most recent definitions concentrate on family culture as a dominant attribute (Litz, 1995; Dreux and Brown, 1994). Although some researchers view the family dimension as a constraint to true entrepreneurial endeavors (Holland and Boulton, 1984), the vast majority of the literature asserts that family businesses constantly achieve a better performance than non-family businesses (McConaughy et al., 2001; Vickers, 1997), by maintaining a competitive advantage through the preservation of the "idiosyncratic knowledge of family character" (Bjuggren and Sudd, 2001).

Although, the family business field has received extensive attention from scholars (Zahra and Sharma, 2004), the research still remains fragmented in its focus and findings (Bird et al., 2002; Chrisman et al., 2003). The most intriguing area in the family business literature that greatly affects the fate of the family firm's entrepreneurial continued positive outcomes is the succession process, as the effective succession rate among family firms is wrought with many difficulties.

\section{MATERIALS AND METHODS}

Succession in the family business: One of the fundamental missions of a family business is to pass the business to subsequent generations (Davis, 1968) and a

Corresponding Author: George S. Vozikis, Department of Management, Institute for Family Business, Craig School of Business, California State University, 5245 N. Backer, M/S PB7, CA 93740-800, Fresno Tel: (559) 278-4965 Fax: (559) 278-7746 
successful succession is the keystone to survival in the family business (Cabrera-Suarez et al., 2001; Shepherd and Zacharakis, 2000; Davis and Harveston, 1998; Barnes, 1988). The family business literature considers succession passage as the most important topic with which a family firm has to deal with (Handler, 1994) and consequently it is one of the most deeply analyzed topics (Poutziouris et al., 2006).

Succession is described as the transfer of leadership from one family member to another (AFBS, 1997). According to the literature, only about $30 \%$ of family firms survive to the second generation and only around $15 \%$ make it through to the third generation (Sonnenfeld, 1991; Morris et al., 1997; Beckhard and Dyer, 1983a; 1983b). In order to most appropriately map an ongoing succession process and identify its critical elements, Handler (1990) identified two interactive succession dimensions, namely, the satisfaction with the succession process and the effectiveness of the succession per se. The majority of research has focused on how families can best prepare to hand the business over to the next generation while very little research has been given to studies that try to discover a set of factors that may prevent intra-family succession. In this study we will try and develop a set of factors that can arise to hinder intra-family succession especially as it pertains to the family farm.

According to (Pyromalis and Vozikis, 2009), the successful succession process whether intra-family or extra-family, i.e., outside the family, entails succession effectiveness and satisfaction with succession by the rest of the family and nonfamily members. Their model focuses on five critical success factors that can influence and assist to a great extent the outcome of the succession process in a family firm: (1) The incumbent's propensity to step aside, (2) the successor's willingness to take over, (3) positive family relations and communication, (4) succession planning and (5) the successor's appropriateness and preparation (Fig. 1).

Factors inhibiting intra-family succession: Previous literature has identified a long list of characteristics and factors that affect the process of succession and specifically the five critical success factors above identified by Pyromalis and Vozikis (2009). In the only research piece we found focusing specifically on the hindering forces of succession (Massis et al., 2008) it was asserted that there are three direct explanations and conditions inhibiting a successful intra-family succession in terms of effectiveness and family satisfaction with succession. Inhibiting a successful intra-family succession in terms of effectiveness and family satisfaction with succession means that succession does not take place, because: (1) all potential family successors decline the managerial leadership of the business, (2) the dominant coalition rejects all potential family successors and (3) the dominant coalition decides against family succession although acceptable and willing potential family successors exist (Fig. 2).

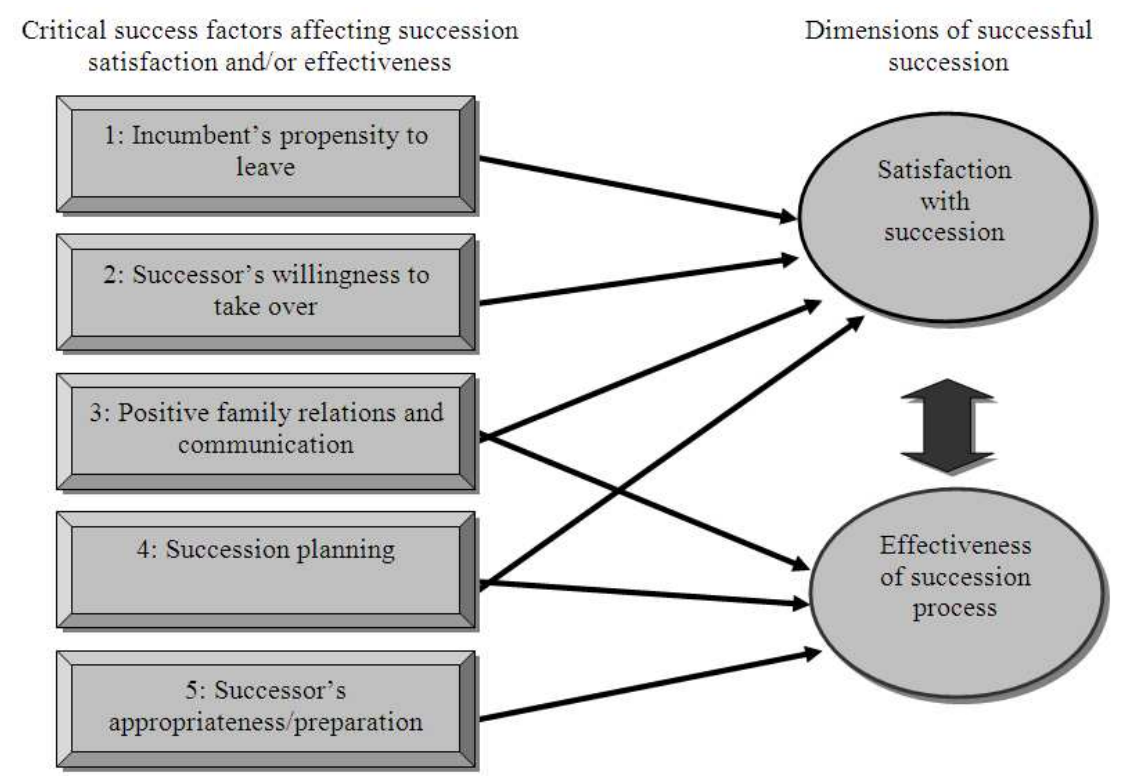

Fig. 1: Conceptual framework of the direct and indirect influences of the critical success factors in the succession process 


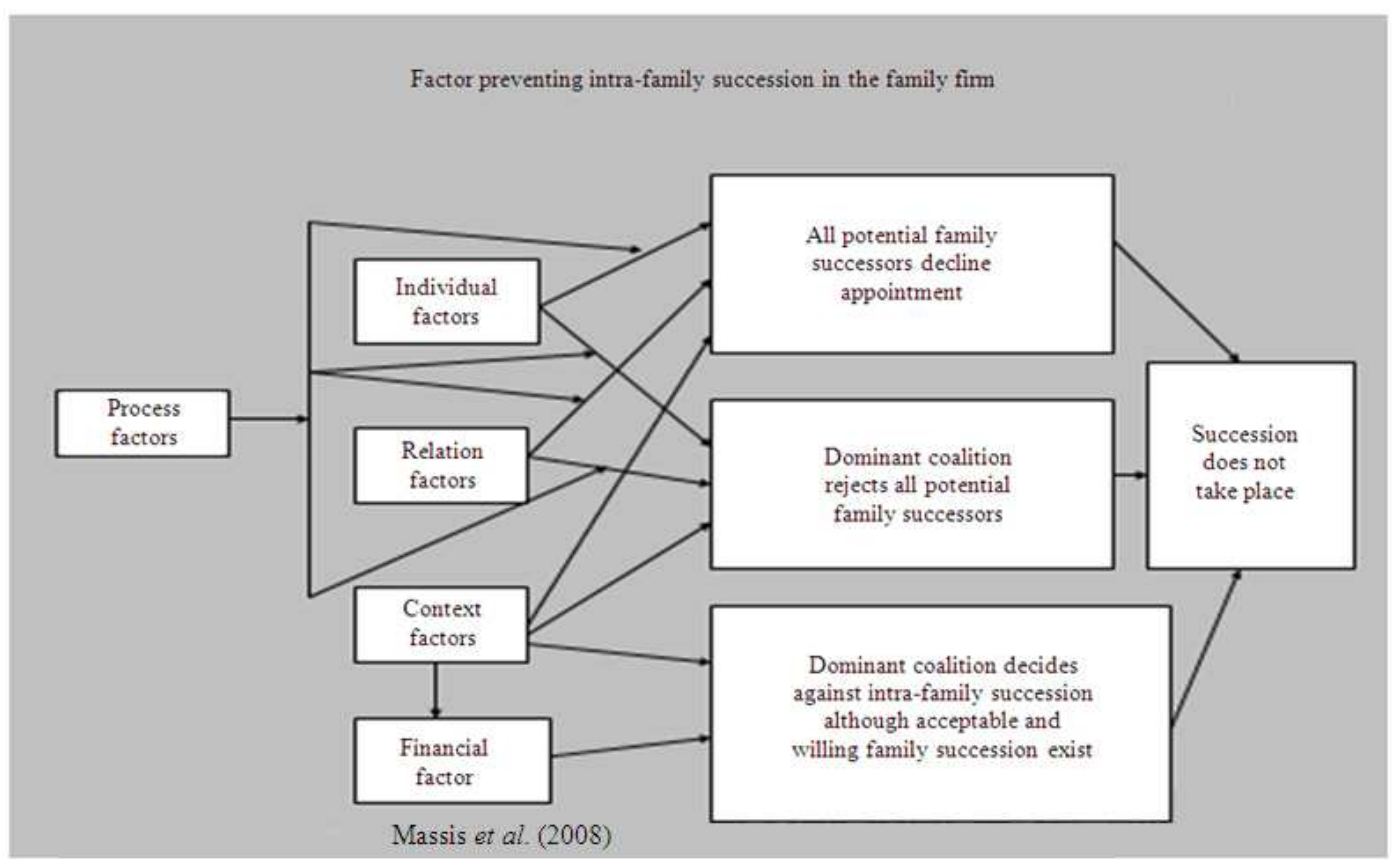

Fig. 2: Factors inhibiting intra-family succession in family firms

If any of these three situations and conditions arises there will be no chance of intra-family succession. These three direct conditions are directly or indirectly included into the (Pyromalis and Vozikis, 2009) conceptual model which pertains to any successful succession whether it is an intra- or extrafamily succession process, therefore it was decided that for this study purposes the broader (Pyromalis and Vozikis, 2009) conceptual framework will be employed rather than the narrower (Massis et al., 2008) model. This research will blend both theoretically and empirically the two conceptual models of (Pyromalis and Vozikis, 2009) assisting critical success factors and Massis et al. (2008) inhibiting conditions as antecedents which impact the effectiveness and satisfaction with the succession process and in turn ultimately thwart or create a successful intra-family succession in a family farm. Our rationale lies in the study by psychologist Kurt Lewin who proposed in his seminal work on force field analysis (1937) that our chances of accomplishing something can be increased if we focus on reducing the factors that prevent the event from occurring rather than increasing the strength of the factors that assist this event (Fig. 3).

The five antecedent issues that inhibit the effectiveness and satisfaction with intra-family succession are according to (Massis et al., 2008): process issues; individual issues, relation issues, context issues and financial issues.
Process issues: These are issues that arise during intrafamily succession planning that may prevent intra-family succession from occurring. Process issues can take different forms: (1) not clearly defining the roles of the incumbent and the potential successor, (2) incorrectly evaluating the gaps between the potential successor's needs and abilities, (3) failing to train the potential successor, (4) late or insufficiently exposing potential successors to the business, (5) not giving the potential successors sufficient feedback about the succession process, (6) not formalizing rational and objective criteria for selection and (7) not defining the composition of the team in charge of the assessment of potential successors. Problems within the antecedent process issues may inhibit the critical success succession factors affecting satisfaction and/or effectiveness with intra-family succession three, four and five, namely, the positive relations and communication within the family, the succession planning and the successor's appropriateness and preparation.

Individual issues: Individual issues include both incumbent and successor related factors. Incumbent related issues include a personal sense of attachment of the incumbent with the business. This strong sense of attachment may prevent them from relinquishing their position and is one of the most frequently cited barriers to effective succession. Another issue that disrupts a lot of intra-family business successions is the unexpected and unplanned for loss of the incumbent. 
Am. J. of Economics and Business Administration 4 (1): 94-104, 2012

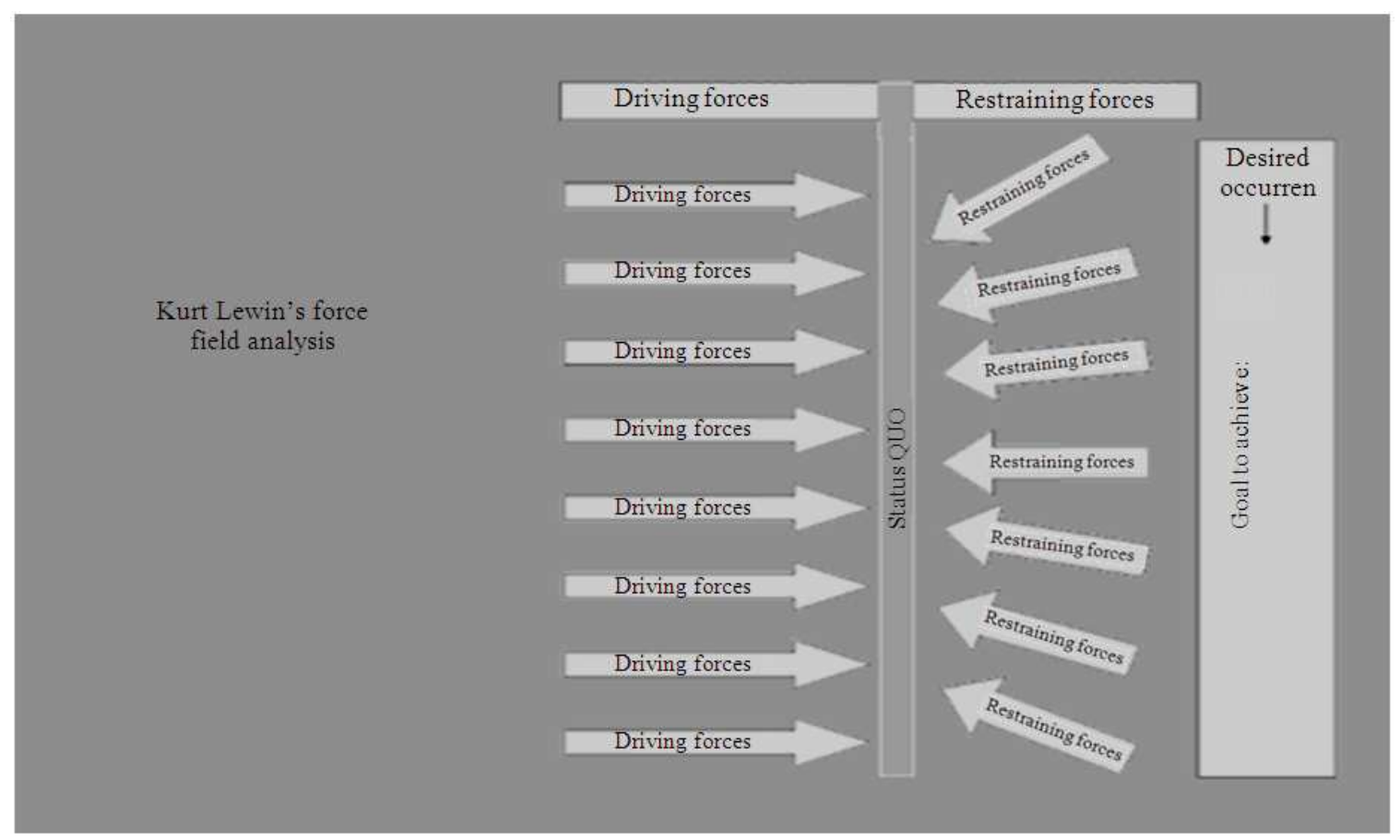

Fig. 3: Lewin's force field analysis as it pertains to intra-family succession of family firms

Successor related factors include the low ability of potential successors, dissatisfaction or lack of motivation of potential successors and the unexpected loss of potential successors. Problems within the antecedent individual issues may inhibit the critical success succession factors affecting satisfaction and/or effectiveness with intra-family succession one and two, namely, the incumbent's propensity to leave and the successor's willingness to take over.

Relation issues: These issues pertain to the relationships between the different interest groups that can cause potential conflicts and prevent succession. These issues include: conflicts/rivalries/competition in parent-child relationships, conflicts/rivalries/competition among family members, perils related to high consensus sensitiveness of the family business such as a requirement for a unanimous vote to make decisions. Lack of trust in the potential successor by family members, a lack of commitment to the potential successor by the family members, conflict between the incumbent/potential successor and nonfamily managers, a lack of trust in the potential successor by non-family managers and a lack of commitment to the potential successors by non-family managers. Problems within the antecedent relation issues may inhibit the critical success succession factors affecting satisfaction and/or effectiveness with intra- family succession two and three, namely, the successor's willingness to take over and the positive relations and communication within the family.

Context issues: These issues involve concerns with a changing economic and/or competitive environment. These issues include: changes in business performance that may alter the family's assessment of the future prospects of the family business and cause changes in the succession process, decreased business scale that could lead the potential successor to leave the business due to decreased perceived monetary rewards and the loss of key customers or suppliers or deterioration in the relationship between potential successors and customers or suppliers. The dominant coalition within the family may decide to shut down the business in the case of weakening future business prospects, or they may seek a more qualified candidate if the business is projecting rapid growth and expansion. Problems within the antecedent context issues may inhibit the critical success succession factors affecting satisfaction and/or effectiveness with intra-family succession one and two namely, the incumbent's propensity to leave and the successor's willingness to take over.

Financial issues: Financial issues are related to limitations in the internal financial resources and the opportunity costs of obtaining external financing. 
Am. J. of Economics and Business Administration 4 (1): 94-104, 2012

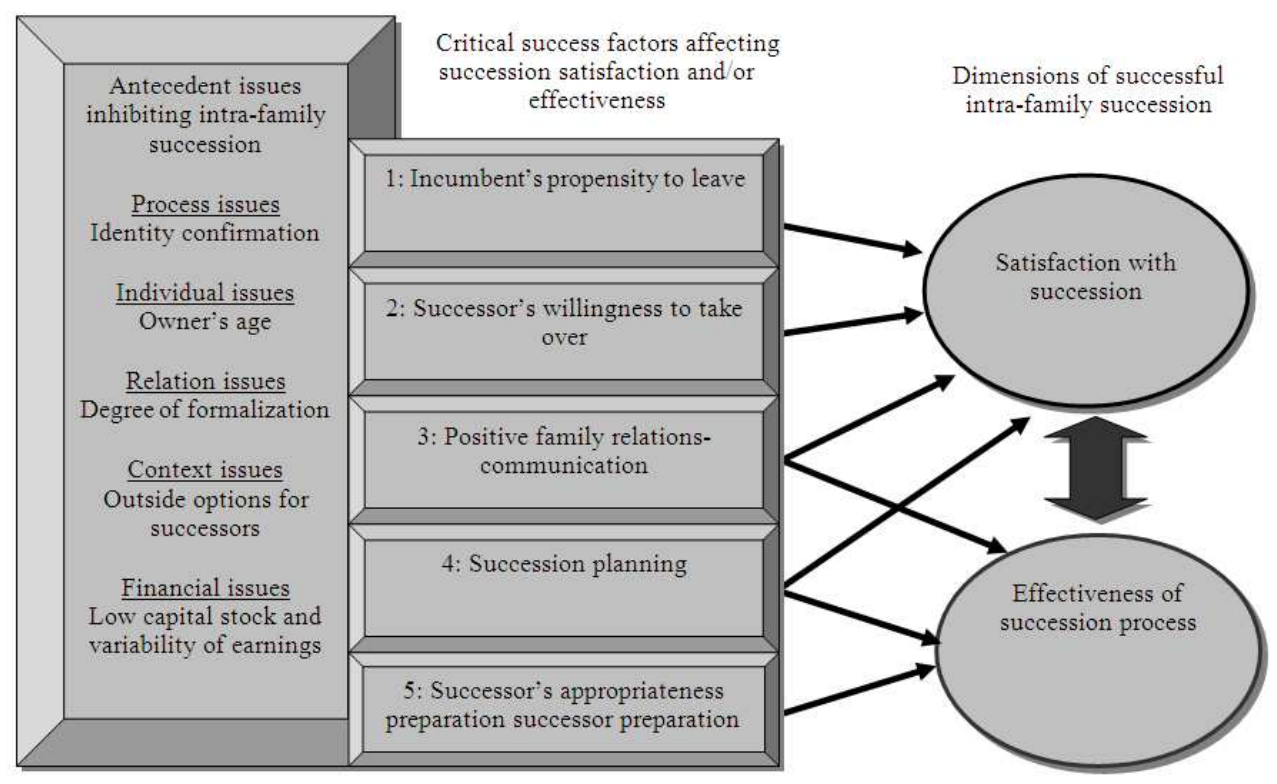

Fig. 4: Conceptual framework of the inhibiting issues within a family owned firm as antecedents on the critical success factors of a successful intra-family succession process

Financial issues include: The ability or inability to sustain the tax burden related to succession, the inability to find the financial resources to liquidate the possible exit of heirs and inadequate financial resources to absorb the costs of hiring professional managers. Problems within the antecedent financial issues may inhibit the critical succession factors affecting satisfaction and/or effectiveness with intra-family succession one, two and five, namely, the incumbent's propensity to leave, the successor's willingness to take over and the successor's appropriateness and preparation, especially when the family firm's dominant coalition does not believe there is a viable reason to keep the business in operation.

Figure 4 depicts the conceptual framework of the direct and indirect influences of the distinct inhibiting issues within family owned firms as outlined above and as antecedents on the critical success factors affecting the effectiveness and the satisfaction of a successful succession process.

It is hoped that the ensuing discussion and research propositions on the antecedent issues inhibiting the critical success factors for effectiveness and satisfaction with an intra-family successful succession and the related research propositions advanced in the rest of the study will give us a much better understanding of the various issues that can arise to inhibit and possibly prevent intrafamily succession. It is the contention of the authors that the forces with the strongest inhibiting force among the various inhibiting issues are: The process issue of identity conformation; the individual issue of the owner's age; the related issue of the family firm's degree of formalization; the context issue of outside options for potential successors and; the financial issues of low capital stock and variability of earnings.

\section{RESULTS}

The expected results confirming the impact of these inhibiting factors on the successful succession in a family firm in terms of succession overall effectiveness and satisfaction with succession, will emerge from the empirical testing of the following propositions.

Research proposition 1: Identity confirmation as a process issue within a family firm will have a stronger inhibiting impact relative to other process issues on the critical success factors of the positive relations and communication within the family, the succession planning and the successor's appropriateness and preparation affecting the effectiveness and satisfaction with intra-family succession.

Some family businesses are in their third or fourth generation and when children are born into these families they are raised with the understanding that they will one day run the family firm. Children born with the last name of Ford, Walton, or Pritzker of the Hyatt Hotels fame, are raised with an understanding of what their future roles in the business will be. They understand what responsibilities they will have and they 
understand what their lives will be like after their time running the business has run its course. Most family businesses though remain in the first or second generation stage and therefore are still working out the details about how incumbents leave and potential successors take over.

In the vast majority of family businesses the current incumbent is the founder as well as its current leader. Generally, as the founder of the business, the incumbent had no other role in his or her adult life other than their role as the head of the family business. This is a role they were not trained for during their youth and is one in which they have a strong attachment to. Since these incumbents were not prepared for this role during their youth, many of them are unprepared for what will happen to them when they relinquish this role to their eventual successor. The phenomenon of incumbents reluctant to retire finds a lot in the profession of professional sports. Most elite athletes have known nothing other than participation in athletics and when it comes time for them to retire they tend to hang on for too long and find themselves being a detriment to their teams. Business incumbents who try to hang on too long can have the same detrimental effect on their firms. The most cited reason for hanging on to a position for too long is known as an identity conformation (Milton, 2008), which denotes and is derived from the strong ties between incumbents and their role as the leader. The potential handover of power to a successor may cause the incumbent to feel as though they are not only losing their position but they are also losing their identity as a person as well.

Issues arising with identity confirmation are not restricted to those in the position of the incumbent but also arise with potential successors. Family businesses in their third or fourth generation raise their children differently than newly created enterprises. Children of first generation business owners may have never spoken about their potential succession as the leader of the business. These children, never being fully primed to take over the business, usually find their own identities outside of the confines of the business. When they are finally approaching to take over their family business they may face issues that they may have never thought about. They may be uncomfortable being responsible for the financial well-being of various family members and may not welcome the newfound attention being lavished on them by employees and family members alike.

Research proposition 2: The owner's age as an individual issue within a family firm will have a stronger inhibiting impact relative to other individual issues on the critical success factors of the incumbent's propensity to leave and the successor's willingness to take over affecting the effectiveness and satisfaction with intrafamily succession.

Building on the discussion on identity conformation above, it is apparent that the longer an incumbent remains in their current position, the more the person associates their identity with that position. The longer the incumbent remains in their position the more they will identify with their position and the more likely they will be to assume a confrontational attitude when it comes time to allow the potential successor to take over and the more likely intra-family conflict would become a major factor in preventing intra-family succession. Additionally, the longer the incumbent remains in his/her position the older the average age of the potential successor will be and therefore the potential successors will be more likely to have sought their own prospects and fortune outside the family business and thus they may be more likely to refuse when approached about taking over the family firm.

Research has shown that in fact, the older the incumbent is when he or she relinquishes their position as the head of the firm, the less cooperative and more confrontational he or she becomes to the incoming intra-family successor (Marshall et al., 2006). When this occurs the incumbent is less likely to introduce the successor to key stakeholders and to disclose key information that may not be known to others in the firm. This attitude tends to alienate members of the family coalition who view a smooth, effective and satisfying for all intra-family succession as imperative to their future financial well being. Another surprising finding of the (Marshall et al., 2006) study was that as incumbents advances in age they are more likely to have succession plans in place than younger incumbents. It is odd therefore that they take this confrontational stance when they have already planned for their retirement and this is probably because the incumbents feel a strong desire to prove to themselves one last time that they still have the capability to be in charge as they have been all along, even though they realize they must soon relinquish control.

Research proposition 3: The degree of formalization within the family as a related issue within a family firm will have a stronger inhibiting impact relative to other related issues on the critical success factors of the successor's willingness to take over and the positive relations and communication within the family affecting the effectiveness and satisfaction with intra-family succession. 
Poor relationships among key stakeholders may be the most difficult factor to overcome, but there are ways to reduce its chances of hindering succession. The importance of the family firm's formalization in raising the quality level of intra-family succession planning was supported by (Vries, 1977; Fredrickson, 1986), who showed that one of the key factors that most negatively affect succession and overall success among family businesses is the owner's unwillingness to formalize the organization. Although there is no concrete evidence linking the degree of formalization to succession planning, prior studies suggest that increased formalization would have a positive effect on the comprehensiveness of the succession planning process in family owned businesses (Harveston et al., 1997) and that a high degree of organizational formalization contributes to better communication within the business and the family and consequently provides more positive relations and organizational climate.

Research proposition 4: Outside options for potential successors as a context issue within a family firm will have a stronger inhibiting impact relative to other contextual issues on the critical success factors of the incumbent's propensity to leave and the successor's willingness to take over affecting the effectiveness and satisfaction with intra-family succession.

Potential successors can inhibit an intra-family succession by declining the opportunity to take over the family business because of more advantageous outside offers. It was mentioned earlier that as incumbents remained in their positions for longer periods of time, potential successors may have created identities outside of the family business and better economic prospects in their current positions that they may not be readily willing to relinquish easily, even for the sake of their family's overall welfare. Additionally, in first or second generation family businesses positions are raised without having a strong understanding of the family firm's finances. This occurs because many first and second generation businesses usually tend to not place a strong emphasis on their succession plans. Without a strong understanding of the family's and the family firm's finances, potential family successors are forced to take their cues on the health of the business from the outside activities of their parents. Financial cues include what type of home the family resides in, what type of cars they drive and how freely cash is spent on luxuries. One of the best cues on the inherent strength of the family business is the "appearance" of a large inheritance (Schafer and Talavera, 2009). It has been found that the appearance of an inheritance has a strong effect on improving the chances of intra-family succession in family businesses, because it signals to the incoming generation of family leaders that the business is in a strong financial position, has no immediate difficulties raising financial capital and the owners view future prospects to be good enough to pass on extra capital to the next generation. Also, by providing the future generation with a robust inheritance, the successors perceive that they enter the family business on a much stronger individual financial footing than they already do outside the family firm or they could have possibly with other external options, had they not been provided by inheritance. Besides the obvious material benefits of an inheritance, perhaps its strongest impact for a successful intra-family succession is that it removes any economic doubts the potential successors may have. Without an inheritance the successors may feel they are taking on excessive risk by replacing the incumbent at the helm of the family firm and may not be completely confident about the firm's future business prospects.

It is obvious therefore, that a lot of the perceptual beliefs of the incoming generation rise from the signals they see put out by the current leadership. An inheritance, continuing government subsidies and large capital stocks send a strong signal to the incoming generation that the business is on strong financial footing. Conversely, the lack of these factors signals to the incoming generation that the business may not be on strong financial footing and that they may do better by pursuing economic interests outside the firm. A simple way to overcome these signals is to include the future generation of leadership in the economic dealings of the firm so that they do not make any incorrect assumptions about the firm's health, thus, inhibiting the prospects of a successful intra-family succession.

Research proposition 5: Low capital stock and a high variability of earnings in a family firm as a financial issue will have a stronger inhibiting impact relative to other financial issues on the critical success factors of the incumbent's propensity to leave, the successor's willingness to take over and the successor's appropriateness and preparation affecting the effectiveness and satisfaction with intra-family succession.

In what is a very relevant topic for any family business but especially to the family-owned farm the issue of low capital stock is a very serious issue that inhibits a successful succession. One reason familyowned farms are an interesting case study in succession is that they are five times more likely to have an intrafamily succession than any other family-owned business (Laband and Lents, 1983). Interestingly enough, as the educational level of the current 
owner/operator increases there is a higher likelihood that they will have a written succession plan in place. This is countered by the finding that as the educational level of the incoming generation increases, the lower the chances they will accept the opportunity to take over the family farm from the current leadership.

Compared to other types of businesses, family farms have completely different issues inhibiting or improving the chances of intra-family succession. Owners of family farms seem to be more dependent on the future income streams of the business than are owners of other family-owned enterprises. This is evidenced by the finding that there is a higher occurrence of intra-family and overall succession plans at farms where the owners expect to receive retirement income from sources outside of the family business such as pensions or social security (Mishra and El-Osta, 2008). This may be because farms require large capital investments and face a high variability of earnings, which necessitates for farmers to invest a higher percentage of their profits back into the business than other firms, leaving them with less to put away as a security net. Higher capital requirements also lead to another interesting factor for family farms, whereby farmers are more likely to create intra-family succession plans if they plan on continuing to receive government subsidies than if they expect to stop receiving those subsidies sometime in the foreseeable future. We may assume that government subsidies act as a sort of inheritance like we saw above and may signal to the future generation that they will earn a significant enough income to convince them to continue the family farm rather than pursue other opportunities. Also, the larger the capital stocks of the farm the higher the chances of intra-family succession, since the level of capital stocks could also be taken as a signal to the incoming generation about the prospects for success of the farm as a whole.

\section{DISCUSSION}

This study investigated five categories of inhibiting issues for a successful intra-family succession which are important because as Lewin (1935) force field analysis proposed the chances of accomplishing something can be increased if we focus on reducing the issues that prevent the event from occurring rather than increasing the strength of the factors that assist this event. The five antecedent issues that inhibit the effectiveness and satisfaction with intra-family succession and may prevent it from happening all together are according to (Massis et al., 2008): process issues; individual issues, relation issues, context issues and financial issues. It is important that these issues that prevent, inhibit, or hinder intra-family succession are seriously addressed within the family firm and especially the family farm, which as mentioned earlier is five times more likely to have an intra-family succession than any other family-owned business, so that family firms can increase the chances of an effective and satisfactory intra-family succession for all stakeholders.

We identified and stated in the form of research propositions based on the literature review, what we believe to be the strongest inhibiting issues that affect the critical success factors for a successful intra-family succession, namely: individual confirmation as a process issue; the owners' age as an individual issue; the degree of formalization of the family firm as a relation issue; the outside options for potential successors as a context issue and; the low capital stock and the high variability of earnings as a financial issue. All these inhibiting issues are of course interrelated and do not stand totally independent from each other, but rather they need to be viewed as a whole perspective in the quest of a successful intra-family succession. The degree of their inhibiting influence on the critical success factors of an effective and satisfactory succession will vary and depend on the circumstances of both incumbent and intra-family successor, as well as environmental factors specific in time and place and family firm type, as we acknowledged the case to be for family farms.

Additionally, as part of future research undertakings on the subject of a successful intra-family succession we have identified some other issues and factors that need also to be examined and brought to the table.

The first inhibiting factor we identified is that of unclear roles in a family firm. Clearly defining the roles of the potential successor, the incumbent and the family council reduces ambiguity and allows each stakeholder to have an understanding of the decisions that are made in the succession process. Clearly defining roles also allows for the key stakeholders to provide support and consensus to the incumbent and the potential successor.

Another inhibiting factor we can pinpoint is a lack of or a high degree of ambiguity in the succession plan. This factor is an extension of the unclear role factor above and gives the incumbent and successor time to adjust to their future roles in the family and the business. By acknowledging the succession process early on in the life of the incumbent and the potential successor gives them time to prepare for their changing roles and can avert the identity conformation problem by preventing key stakeholders from becoming too attached to their current roles. 
The third factor deals with a lack of reverence accorded to the potential successor from clients and suppliers. While some issues with this factor may be remedied by training the potential family successor and by increasing his or her exposure in the family firm's dealings in order to enhance their credibility and visibility, this is still a quite serious problem. One of the reasons that clients and customers may not trust the incoming successor is because they have not enough time to get to know the individual. By introducing the potential successor to these key stakeholders early and often, clients and suppliers will have time to develop a relationship with the incoming successor and therefore allow for a smooth transition when the current incumbent leaves his or her position.

Another inhibiting factor impacting the critical success factors of a successful intra-family succession is the inability to sustain the tax burden of handing the business over to a new generation. This is probably the most easily overcome factor because of the ability to purchase a life insurance policy that will cover the estate taxes when the owner of the business passes away.

A final critical inhibiting factor is the lack of education or the poor skills among potential successors. When potential successors have poor education or poor skill levels they may lack self-efficacy, self-esteem and overall confidence and thus may not wish to take on the challenge of running the family business and/or the family council may not want to allow the potential successor take over the business. Poor skills can be overcome by evaluating the skill gaps in the potential successor early and repeating this analysis often. Providing early training and exposing the potential successor to the business early on in their lifetime will allow potential successors to better prepare and gain the experience and knowledge necessary to take over the business when it is time for the incumbent to retire. In contrast, farming is an occupation where the educational level plays a much smaller role in the success of the owners than other family firms in other industries.

By identifying and measuring the impact of these factors and issues that act as barriers inhibiting a successful intra-family succession as part of future research undertakings we can increase the chances of an effective and satisfactory intra-family succession.

\section{CONCLUSION}

The majority of family business research has focused on how families can best prepare to hand the business over to the next generation while very little research has been devoted to studies that try to discover a set of factors that may prevent intra-family succession. In this study we developed a conceptual framework and research propositions on the antecedent issues both inhibiting and promoting the critical success factors for effectiveness and satisfaction with an intrafamily successful succession and the related research. The propositions advanced here when empirically tested, will hopefully give us a much better understanding of the various issues that can arise and inhibit and possibly prevent intra-family succession. It is the contention of the authors that the forces with the strongest inhibiting force among the various inhibiting issues are: The process issue of identity confirmation; the individual issue of the owner's age; the related issue of the family firm's degree of formalization; the context issue of outside options for potential successors and; the financial issues of low capital stock and variability of earnings. As mentioned earlier there are additional inhibiting factors that could also be investigated further and can be incorporated in the conceptual framework to shed additional light into the always murky picture of family business succession.

\section{REFERENCES}

AFBS, 1997. The Arthur Andersen/Mass Mutual. American Family Business Survey.

Astrachan, J.H., S.A. Zahra and P. Sharma, 2003. Family-sponsored ventures. Proceedings of the 1st Annual Global Entrepreneurship Symposium: The Entrepreneurial Advantage of Nations, Apr. 29-29. United Nations Headquarters, pp: 1-15.

Barnes, L.B. and S.A. Hershon, 1976. Transferring power in the family business. Harvard Bus. Rev.

Barnes, L.B., 1988. Incongruent hierarchies: Daughters and Younger Sons as Company CEOs. Family Bus. Rev., $\quad$ 1: $\quad 9-21$. DOI: $10.1111 / \mathrm{j} .1741-$ 6248.1988.00009.x

Beckhard, R. and J.W. Dyer, 1983a. Managing change in family firm-issues and strategies. Sloan Manage. Rev., 24: 59-65.

Beckhard, R. and W.G. Dyer Jr., 1983b. Managing continuity in the family-owned business. Organ. Dynamics, 12: 5-12. DOI: 10.1016/00902616(83)90022-0

Bird, B., H. Welsch, J.H. Astrachan and D. Pistrui, 2002. Family business research: The evolution of an academic field. Family Bus. Rev., 15: 337-350. DOI: 10.1111/j.1741-6248.2002.00337.x

Bjuggren, P.O. and L.G. Sudd, 2001. Strategic decision making in intergenerational successions of smalland medium-size family-owned businesses. Family Bus. Rev., 14: 11-24. DOI: 10.1111/j.17416248.2001.00011.x 
Burch, P.H., 1972. The Managerial Revolution Reassessed: Family Control in America's Large Corporations. 1st Edn., Lexington Books, Lexington, MA., ISBN-10: 066981430X, pp: 195.

Cabrera-Suarez, K., P.D. Saa-Perez and D. GarciaAlmeida, 2001. The succession process from a resource- and knowledge-based view of the family firm. Family Bus. Rev., 14: 37-46. DOI: 10.1111/j.1741-6248.2001.00037.x

Chrisman, J.J., J.H. Chua and P. Sharma, 2003. Current trends and future directions in family business management studies: Toward a theory of the family firm. The Pennsylvania State University.

Davis, P.S. and P.D Harveston, 1998. The influence of family on the family business succession process: A multi-generational perspective. Entrepreneurship: Theory Pract.

Davis, S.M., 1968. Entrepreneurial succession. Admin. Sci. Q., 13: 402-416.

Dreux, I.V.D.R. and B.M. Brown, 1994. Marketing private banking services to family businesses. Int. J. Bank Market., 12: 26-35. DOI: $10.1108 / 02652329410055187$

Dyer, W.G., 1986. Cultural Change in Family Firms: Anticipating and Managing Business and Family Transitions. 1st Edn., Jossey-Bass, San Francisco, pp: 179.

Fredrickson, J.W., 1986. The strategic decision process and organizational structure. Acad. Manage. J., 11: 280-297.

Handler, W.C., 1990. Succession in family firms: A mutual role adjustment between entrepreneur and next-generation family members. Entrepreneurship Theory Pract., 15: 37-51.

Handler, W.C., 1994. Succession in family business: A review of the research. Family Bus. Rev., 7: 133157. DOI: 10.1111/j.1741-6248.1994.00133.x

Harveston, P.D., P.S. Davis and J.A. Lyden, 1997. Succession planning in family business: The impact of owner gender. Family Bus. Rev., 10: 373-396. DOI: 10.1111/j.1741-6248.1997.00373.x

Holland, P.G. and W.R. Boulton, 1984. Balancing the "Family" and the "Business" in family business. Bus. Horizons, 27: 16-21.

Laband, D.N. and B.F. Lentz, 1983. The family and an incomplete annuity market. J. Agric. Econ., 36: 372-391.

Lewin, K., 1935. A Dynamic Theory of Personality. 1st Edn., McGraw-Hill, New York, pp: 286.

Litz, R.A., 1995. The family business: Toward definitional clarity. Family Bus. Rev., 8: 71-81. DOI: $10.1111 /$ j.1741-6248.1995.00071.x
Marshall, J.P., R. Sorenson, K. Brigham, E. Wieling and A. Reifman et al., 2006. The paradox for the family firm CEO: Owner age relationship to succession-related processes and plans. J. Bus. Ventur., 21: 348-368. DOI: 10.1016/j.jbusvent.2005.06.004

Massis, A.D., J.H. Chua and J.J. Chrisman, 2008. Factors preventing intra-Family succession. Family Bus. Rev., 21: 187-199. DOI: 10.1111/j.17416248.2008.00118. $\mathrm{x}$

McCann, G. and N.B. Bowman-Upton, 2001. The Holistic Model: Destroying Myths and Creating Value in Family Business. 1st Edn., Family Business Center, Stetson University, DeLand, FL., pp: 71.

McConaughy, D.L., C.H. Matthews and A.S. Ftalko, 2001. Founding family controlled firms: performance, risk and value. J. Small Bus. Manage., 39: 31-49. DOI: 10.1111/04472778.00004

Milton, L.P., 2008. Unleashing the relationship power of family firms: Identity confirmation as a catalyst for performance. Entrepreneurship Theory Pract., 32: 1063-1081. DOI: 10.1111/j.15406520.2008.00273.x

Mishra, A.K. and H.S. El-Osta, 2008. Effect of agricultural policy on succession decisions of farm households. Rev. Econ. Household, 6: 285-307. DOI: $10.1007 / \mathrm{s} 11150-008-9032-7$

Morris, M.H., R.O. Williams, J.A. Allen and R.A. Avila, 1997. Correlates of success in family business transitions. J. Bus. Ventur., 12: 385-401. DOI: 10.1016/S0883-9026(97)00010-4

Poutziouris, P., 2001. The (Re)-Emergence of Growth Vis-a'-Vis Control Dilemma in a Family Business Growth Star: The Case of the UK Taramasalata Kings. In: Family Business Research in the Third Millennium - Building Bridges between Theory and Practice, Poutziouris, P. and D. Pistrui (Eds.). The Family Firm Institute Publication, Boston, MA., pp: 88-103.

Poutziouris, P., K. Smyrnios and S. Klein, 2006. Handbook of Research on Family Business. 1st Edn., Edward Elgar Publishing, Cheltenham, ISBN-10: 1845424107, pp: 631.

Pyromalis, V.D. and G.S. Vozikis, 2009. Mapping the successful succession process in family firms: Evidence from Greece. Int. Enter. Manage. J., 5: 439-460. DOI: 10.1007/s11365-009-0118-3

Schafer, D. and O. Talavera, 2009. Small business survival and inheritance: Evidence from Germany. Small Bus. Econ., 32: 95-109. DOI: 10.1007/s11187-007-9069-7 
Shepherd, D.A. and A. Zacharakis, 2000. Structuring family business succession: An analysis of the future leader's decision making. Entrepreneurship Theory Pract.

Sonnenfeld, J., 1991. The Hero's Farewell: What Happens When CEOs Retire. 1st Edn., Oxford University Press, New York, ISBN-10: 0199839166, pp: 336.

Vickers, M., 1997. For long-haul performance, consider all the best families. The New York Times Company.

Vries, M.F.R.K.D., 1977. The entrepreneurial personality: A person at the crossroads. J. Manage. Stud., 14: $34-58 . \quad$ DOI: $10.1111 /$ j.14676486.1977.tb00616.x
Ward, J.L., 2010. Keeping the Family Business Healthy: How to Plan for Continuing Growth, Profitability and Family Leadership. 1st Edn., Palgrave MacMillan, New York, ISBN-10: 0230111211, pp: 286.

Zahra, S.A. and P. Sharma, 2004. Family business research: A strategic reflection. Family Bus. Rev., 17: $\quad 331-346 . \quad$ DOI: $\quad 10.1111 / \mathrm{j} .1741-$ 6248.2004.00022.x 